\title{
O selvagem e a História. Heródoto e a questão do Outro
}

\author{
Klaas Woortmann \\ Professor do Departamento de Antropologia - UnB
}

\begin{abstract}
RESUMO: O artigo procura examinar os limites impostos pela teoria da história no pensamento grego para a compreensão da alteridade. Tal teoria, fundada na oposição entre epistéme e doxa, minimiza o significado do particular e do evento em seu significado próprio, tornando difícil o desenvolvimento de uma etnografia. Nesse contexto de idéias, é dada particular ênfase ao papel desempenhado pelos citas, percebidos como "selvagens", na História de Heródoto.
\end{abstract}

PALAVRAS-CHAVE: selvagem, pensamento grego, história, citas, Heródoto, particular, evento, mitologia, bárbaros.

A partir das navegações empreendidas pelos portugueses e da chegada de Colombo à América, uma nova humanidade ingressou no horizonte mental europeu. Perante ela, a Europa foi gradativamente forçada a se repensar. Ao mesmo tempo, os europeus tiveram que pensar o ameríndio, assim como os vários outros povos com que foram se defrontando pelo mundo afora. Nesse processo, surge um novo "selvagem", transposição para o Novo Mundo de construções de alteridade já existentes no imaginário europeu e em boa medida herdadas do pensamento antigo. Meu objetivo aqui é o de examinar o significado do "selvagem" no pensamento grego antigo, dando especial destaque a Heródoto (1988: 1).

Como mostra Hodgen (1964), o pensamento grego clássico não privilegiava estudos comparativos nem a compreensão do particular, o que dificultava a apreciação da alteridade. 
KlaAs Woortmann. O selvagem e a História. Heródoto e a questão do outro

Como propunha Aristóteles em sua Política, só realizava a plenitude da humanidade o homem que vivia na pólis. Em outras palavras, quem não era grego era bárbaro, ou até mesmo selvagem.

Selvagem não significava necessariamente bárbaro, ou vice-versa: na verdade, o selvagem já existia no domínio da mitologia antes que o bárbaro ingressasse no plano da história. Como diz Bartra (1994), o selvagem teve de ser inventado antes de ser encontrado.

Se o bárbaro e o selvagem podiam ser tematizados, e precisavam sêlo, como condição para a tematização da própria identidade grega e da pólis, pouco interesse havia no conhecimento de povos concretos, fossem eles caracterizados ou não como selvagens. Mas havia exceções, e Heródoto é provavelmente a mais importante.

Por outro lado, o pensamento científico dominante negava o particular como significativo em si mesmo. A história, limitada à doxa (opinião), se diferenciava da epistéme (ciência). O único objeto do conhecimento pleno era o imutável e o pensamento grego atingiu tal conhecimento na matemática. $O$ conhecimento matemático é válido em qualquer tempo e lugar. Na natureza as coisas se transformam; portanto, não podiam ser plenamente conhecidas e a teoria grega da história era consistente com sua teoria da natureza:

A história é uma ciência da ação humana: o que o historiador vê à sua frente são coisas que os homens fizeram no passado, coisas essas que pertencem a um mundo em transformação, um mundo em que aparecem e desaparecem coisas. Tais coisas, de acordo com a concepção metafísica preponderante na antiga Grécia, não seriam cognoscíveis. Conseqüentemente, a história seria impossível. (Collingwood, 1994: 35)

O objeto do conhecimento histórico era ainda mais volúvel que a natureza. Para Platão, o mundo transitório é verdadeiro, mas não inteligível. Uma história científica seria impossível, pois o transitório não é passível de demonstração.

Isso não significa que os gregos se desinteressassem pela história: seus mundos social e natural eram mundos em rápida e intensa transformação 
e os gregos reconheciam a necessidade da transformação. A concepção grega de história não era determinista, visto que seu curso podia ser mudado pela vontade dos homens. Contudo, a ação do homem permaneceininteligível em suas causas. Sua visão de mundo incorporava a noção da inevitável transformação de uma situação no seu contrário, mas as causas não podiam ser conhecidas.

A história diz-nos que Cresus e Polícrates caíram na desgraça; a poesia, segundo a idéia que dela fazia Aristóteles, não faz esses juízos singulares e sim o juízo universal de que os homens muito ricos... caem em desgraça. Mesmo este é, na opinião de Aristóteles, apenas um juízo parcialmente científico, pois ninguém consegue saber por que razão os ricos hão de cair na desgraça... a poesia é para Aristóteles a essência extraída dos ensinamentos da história. Na poesia, as lições da história [permanecem] sem demonstração... embora se tornem... mais úteis. (Collingwood, 1994: 40)

Para Aristóteles, então, a poesia estaria mais próxima da ciência que a história: esta última é um amontoado de fatos empíricos desordenados, enquanto a poesia pode deles extrair juízos universais.

A medicina e mais particularmente a psicologia hipocrática levariam, em Tucídides, a uma "história psicológica", uma espécie de ciência natural: não são os eventos particulares que lhe interessam, mas as leis gerais que os explicam. Se essas leis são imutáveis, são cognoscíveis, mas a história tornase, então, anti-histórica! Em Tucídides, o pensamento

...não pode concentrar-se plenamente nos próprios acontecimentos, mas está constantemente a afastar-se deles para transmitir a lição neles implícita, alguma verdade imutável e eterna, da qual os acontecimentos são paradigmas e imagens. (ibid.: 48)

Havia, então, uma consciência histórica na antigüidade grega, mas era uma consciência que, subjugada pela idéia de ciência, pouco espaço concedia à particularidade ou ao evento singular em seu significado próprio. Na medida em que a "metafísica da história" negava a particularidade, ela não estimulava a compreensão do Outro. 
KlaAs Woortmann. O selvagem e a História. Heródoto e a questão do outro

Nesse contexto, Heródoto surge como exceção. Mas qual era a história por ele praticada?

Podemos dizer que ele se dedicava ao que hoje chamamos "memória", ou "história oral", objeto/método tanto de historiadores como de antropólogos. Para Ariès (1989), o que ele fazia era uma espécie de etnografia pela via da memória de "testemunhas oculares" cujos depoimentos eram submetidos à crítica de maneira semelhante àquela utilizada em processos judiciais.

Heródoto trabalhou com uma hierarquia de informantes, tanto mais confiáveis quanto mais próximos dos acontecimentos. Como sugere Darbo-Peschansky (1998: 105), ele considerava que era "melhor dirigirse aos indígenas ou aos cidadãos, conforme estejam em causa seu país ou sua cidade". Mas é um critério apenas formal, pois

...um argivo ...pode ser levado como tal a falar das desavenças de Argos com... Esparta, sem no entanto tê-las presenciado, por não ter sido seu contemporâneo ou por não ter estado exatamente no local em questão... É evidente que Heródoto não leva em consideração a situação de seus informantes ao prestarem o seu depoimento [nem] sua posição em face dos acontecimentos...; também as condições políticas, econômicas, subjetivas, que permitiriam distinguir suas intenções e calcular-lhes os efeitos. Sabe-se apenas que eles vivem no perímetro de onde brotou o primeiro testemunho direto do acontecimento... Mas... não faltam razões para suspeitar dos relatos de tais informantes... [dada] a modificação de um relato na medida em que ele é transmitido... [e] a elaboração de uma lenda patriótica ou de uma versão que privilegia os interesses ou a imagem consagrada de uma instituição ou de um personagem qualquer do país. Acontece que Heródoto não manifesta nenhuma dessas objeções... a sua investigação não se ocupa nem em verificar a presença do informante nos acontecimentos, ...nem os fatores de reelaboração dos fatos pelo discurso. (ibid.)

Não se justifica, então, comparar seu método à investigação judicial, como quer Ariès. Vista através de um olhar atual, sua objetividade era um tanto relativa. Sua hierarquia de informantes tinha ainda uma outra dimensão, bastante relevante para os propósitos deste trabalho: o grau de contato 
entre um povo e os gregos determina o crédito que ele merece. Assim, diz Darbo-Peschansky (ibid.), os citas podem ser ouvidos porque fazem fronteira com os gregos do Ponto, enquanto os povos mais afastados são ouvidos com desconfiança. No entanto, a leitura da História mostra que também os citas são ouvidos com desconfiança, quando o relato de sua própria origem é contraposto ao dos gregos do Ponto; os citas se tornam, então, “distantes".

Esse... critério de avaliação dos informantes, que introduz uma geografia de valores na qual a Grécia representa o pólo de referência, vem evidentemente modificar e restringir o alcance do critério anteriormente estudado, segundo o qual se devem escutar os indígenas quando sua própria terra está em questão. (Darbo-Peschansky, 1998:107)

Desde um ponto de vista espacial, é como se a hierarquia de informantes se dispusesse em círculos concêntricos em torno à Grécia e o grau de confiabilidade fosse inversamente proporcional ao afastamento relativo a esse centro.

Havia, ainda, uma dimensão temporal: dentre todos os informantes, os egípcios seriam os mais confiáveis. Eles possuíriam uma "competência universal", pois são confiáveis mesmo quando falam dos outros. Isto porque são o mais antigo dos povos (em contraposição aos citas, construídos como o mais jovem). Eles seriam contemporâneos de acontecimentos que outros povos não poderiam ter presenciado, porque souberam, por meio de cultos e rituais, manter os laços com o passado.

Se Heródoto, na contramão das tendências dominantes de sua época, postulava uma história que era uma etnografia, essa história incluía os bárbaros, desde o Egito até os persas, e mesmo os "selvagens" citas, que serão aqui destacados. Não se conclua, porém, que se tratava de um interesse pelos citas em si mesmos. Como se verá adiante, a História de Heródoto tinha como tema a guerra contra Xerxes e os citas só comparecem em função de sua própria guerra anterior contra Dario.

$* * *$ 
KlaAs Woortmann. O selvagem e a História. Heródoto e a questão do outro

No pensamento grego a noção de selvagem denotava tanto aqueles que não falavam grego, o que chegava a ser equivalente a não possuir linguagem, quanto significava crueldade. Podia significar também desconhecimento da agricultura (ou da noção grega de agricultura, relacionada ao oikos). Em conjunto, essas noções serviam sobretudo para construir uma identidade grega. Como observa Bartra (1994), os gregos não tinham um termo discreto para denotar a noção de civilização. Para expressar tal noção utilizavam as palavras/conceito pólis (cidade) e hemeros (domesticado). Combinadas, transmitiam a idéia de ordem, a cidade governada por leis justas; fora da cidade só poderia existir desordem ou tirania.

O que se opõe polarmente ao civilizado é o selvagem. Como já foi dito, para melhor expressar a noção de civilização, o pensamento grego primeiro criou o selvagem; mais tarde o projetou sobre povos específicos.

Uma das principais representações do homem selvagem era o centauro, híbrido de homem e cavalo. Não existiam apenas centauros individuais, mas tribos de centauros que habitariam a Tessália e a Arcadia. Além dos centauros existia uma série de outros seres selvagens, desde os cíclopes até as ninfas. De um lado, eram seres (ou povos) violentos e cruéis; de outro, eram selvagens, no sentido de silvestres, mas justos, sábios e bondosos. Mas num e noutro caso opunham-se à cidade: eram os agrios, habitantes do agros, espaço simbólico que se opunha à pólis, tal como os romanos iriam opor ao mundus da ordem o imundus do caos.

Por outro lado, como nota White (1994), o selvagem mítico era percebido como uma ameaça e em oposição à civilização. Os centauros são um bom exemplo. Como indivíduos monstruosos ou como tribos, descritos de diferentes maneiras, eram fundamentalmente um meio termo entre humanos e não-humanos, isto é, seres liminais. O "encontro mitológico" entre o grego e o centauro é paradigmático para o futuro "encontro etnográfico" entre gregos e povos tidos como selvagens.

No relato mítico do encontro de Heraclés com o centauro Pholus (Bartra, ibid.: 15) se vê que o selvagem/centauro desconhecia a agricultura 
(domesticação da natureza). Naquele encontro, enquanto Heraclés comia carne cozida, Pholus comia carne crua. Quando Pholus oferece vinho, nem cru nem cozido, seu cheiro excita outro centauro, sintomaticamente chamado Agrios, que ataca Heraclés.

O mito parece evocar um jogo "estruturalista": uma oposição cru/cozido (natureza/cultura) mediada ao mesmo tempo pela comensalidade (troca; comportamento racional) e pela embriaguês (vinho fermentado; perda da razão) que leva à negação da troca. De um lado, o mito constrói o contraste entre o civilizado e o selvagem "natural"; mas ele expressa também, metaforicamente, a relação instável entre a persona civilizada que habita a pólis e é por ela domesticada, e o "selvagem interior" que habita o indivíduo dentro da mesma pólis e constantemente a ameaça. Nunca é demais lembrar que a cidade grega, como Aristóteles deixa claro em sua Política, é uma totalidade onde não há lugar para o individualismo e que um dos múltiplos significados do selvagem e da embriaguês é o do indivíduo livre das amarras da pólis.

O relato míticoé uma reflexão sobre a relação entre natureza e civilização, relação problemática em todo o pensamento ocidental, na qual a natureza parece ser uma categoria central do pensamento ao mesmo tempo que é um estado a ser suplantado. O encontro entre o herói civilizador e o centauro expressa, então, o contraste entre a natureza selvagem e a civilização, tema adotado por Sófocles como base para a Trachiniae.

O mito reflete ao mesmo tempo sobre o encontro com um Outro "geográfico" - o mesmo Heraclés é o demiurgo mítico na criação dos citas. É um jogo de alteridades na difícil relação com esse Outro radicalmente exótico, tão problemático e necessário quanto o selvagem mítico para a afirmação de uma identidade grega.

Também os cíclopes eram a negação do princípio da hospitalidade. Canibais, eles não trocam mas devoram o Outro, como que numa "reciprocidade negativa" (Sahlins, 1978). Descritos na Odisséia como um povo de pastores gigantes, antropófagos que não conheciam a agricultura e que viviam isolados, ferozes mas também idílicos, eram semelhantes aos 
KlaAs Woortmann. O selvagem e a História. Heródoto e a questão do outro

arimaspos com apenas um olho, descritos por Heródoto como canibais, ferozes, sem leis, pastores como os citas. Num certo plano, o cíclope e Phorus se equivalem, pois se este último aceita a troca e convive, por outro lado come carne crua. Coloca-se, pois, no pólo oposto ao do grego civilizado. Mas Phorus e cíclopes se colocam eles mesmos em pólos opostos dentro da selvageria, visto que Phorus é como que o "bom selvagem", o selvagem justo e hospitaleiro. Centauros, seres liminais, expressavam a ambigüidade presente na representação da alteridade. "Eles formaram um mito com dois pólos, um do homem selvagem humanóide e outro do homem sábio e justo que era bestial" (Bartra, 1994: 16).

Vale ressaltar que canibalismo, gigantismo, desconhecimento da agricultura, comer cru etc. permaneceram atributos do selvagem até o encontro com os ameríndios.

Mitologia e etnografia tendiam a se misturar à medida que os gregos intensificavam suas relações com outros povos. Essa mistura produziu diferentes idéias, entre elas a de uma Idade de Ouro, idade em que os homens eram selvagens. Era o tempo de Kronos, não inteiramente diferente do tempo edênico do primeiro homem cristão; um tempo em que não era necessário trabalhar, retratado por Hesíodo como o tempo em que a ordem da diké predominava sobre a arrogância da hybris (o ultraje contrário à lei natural) que conduziu a humanidade à decadência (ibid.: 11).

Havia, pois, um princípio de temporalidade envolvido na representação daquele selvagem ambíguo, por vezes concebido como estado e por vezes como estágio; por vezes como ser mítico e por vezes como povo imaginado.

Além dos centauros, outros seres, as amazonas, mulheres com características masculinas, habitavam o espaço imaginário que se contrapunha simbolicamente à pólis; se as mulheres "normais" já eram, de certa forma, percebidas como seres liminais, mais próximas da natureza que da cultura e, como em Aristóteles, inferiores em razão aos homens, as amazonas, com uma carga ainda maior de ambigüidade, guardavam a fronteira entre espaços liminais fundamentais para a cosmologia grega. 
As amazonas (a-mazós, sem seios) se inscrevem na oposição/ complementaridade entre guerra e casamento (homens e mulheres), como a inversão de tal complementaridade. Segundo Estrabão, elas repudiavam o casamento. Encontravam-se sexualmente com homens de outro povo aos quais entregavam seus filhos, se do sexo masculino, mantendo consigo apenas as meninas. Para Deodoro da Sicília, as amazonas, localizadas para além da Líbia, nas fronteiras do mundo habitado, se casam, mas são os homens que desempenham as tarefas "femininas", domésticas. No entanto, as amazonas só são guerreiras enquanto virgens; a partir do primeiro parto, deixam a atividade guerreira para adotar a atividade política. Isto parece significar que as amazonas são como que helenizadas: enquanto guerreiras, dimensão que mais as contrasta, correspondem a um grupo de idade; são, na verdade, uma espécie de efebos (Hartog, 1980: 230). Assim uma alteridade das "fronteiras do mundo" ganha uma familiaridade que a torna inteligível para a cultura que a construiu.

Outra observação é fundamental: as batalhas com amazonas $e$ centauros parodiavam as batalhas entre gregos e bárbaros. A noção de bárbaro só se consolidou após as guerras cujo relato imortalizou Heródoto; aplicando aos bárbaros a selvageria previamente definida pelos mitos, os gregos

...transformaram alegoricamente a guerra contra os bárbaros... numa luta contra centauros e amazonas... Amazonas e centauros eram meios simbólicos para ressaltar a alteridade selvagem dos inimigos, atribuindolhes características típicas dos agrios gregos. (Bartra, 1994: 19)

O selvagem mitológico podia ser, pois, projetado sobre o bárbaro em decorrência da história. Â medida que os contatos com outros povos se intensificavam, isto é, à medida que a história se expandia no espaço, as amazonas foram sendo projetadas para as fronteiras cada vez mais remotas entre o hemeros e o agros, juntamente com os, hiperbóreos, etíopes, gorgons e atlantes de Heródoto. Amazonas, centauros, cíclopes, cinocéfalos etc. eram seres liminais que mediavam o limite entre os espaços 
KlaAs Woortmann. O selvagem e a História. Heródoto e a questão do outro

simbólicos do domesticado e do selvático, da ordem e da desordem, da pólis e do caos.

$$
* * *
$$

Existiam também povos selvagens "reais", e não apenas amazonas e seres teratológicos como os centauros. Os citas, habitantes dos limites do mundo, foram um desses povos; sintomaticamente, as amazonas desempenham um papel fundamental na construção grega da alteridade dos citas.

No imaginário dos gregos os citas são a antítese da civilização, possibilitando o contraste para a construção da identidade helênica.

A Cítia é um lugar selvagem: terra de eremia (deserto) e região de eschatiá (confins do mundo). No Prometeu acorrentado tanto quanto no Dos ares, das águas e dos lugares de Hipócrates, a Cítia é a margem do mundo habitado. Aristófanes usa a expressão "deserto cita" para se referir a um personagem, "selvagem bruto e sem amigos". Quando Alexandre tenta conseguir o que Dario não conseguira, os próprios citas lhe teriam dito que sua região era inexpugnável e que eles preferiam o deserto à ausência de civilização, rejeitando a cidade (Hartog, 1980). Não é demais lembrar que também para a tradição judaica deserto é lugar de selvageria.

Ademais, os citas eram percebidos como nômades que desconheciam a agricultura, atributos até hoje aplicados ao selvagem; seu país se localizava "para além das culturas". Segundo o senso comum grego, o cita é nômade e o nômade é cita. Foi pela intercambialidade entre "nômade" e "cita", entre "deserto" e "cita", acrescentada de algumas caracterísitcas físicas como uma "calvície natural" resultante do frio, que se construiu a alteridade exótica dos citas e sua "selvageria".

O nomadismo é um modo de vida aberrante que só se define negativamente: os nômades não comem pão e freqüentemente comem cru; não trabalham (e veja-se o significado do trabalho agrícola na Política de Aristóteles); não moram em casas; não edificam templos para seus deuses. 
O nomadismo é uma soma de ausências; sempre o oposto do modo de vida grego, sempre referido pelo que ele não é; nunca pelo que é, pois o nomadismo é indizível. O nômade é também primitivo, correspondendo aos primeiros tempos da humanidade, anteriores a Prometeu.

Os nômades vivem numa espécie de Idade de Ouro, livres do trabalho e onde o rebanho ocupa o lugar da terra. Essa idade, como foi visto, era também a idade de Kronos.

...para figurar a vida desses homens que ignoram o trabalho agrícola, Aristóteles não pode evitar o uso de uma metáfora, precisamente agrícola: estação após estação eles se deslocam "como se cultivassem um campo vivo". Não se poderia exprimir mais claramente a impossibilidade de pensar o nomadismo: não tendo palavras para dizê-lo, Aristóteles muda de código e recorre à metáfora que, finalmente, não faz senão reafirmar como redundância que o nomadismo não é bom de pensar. (Hartog, 1980: 219)

Hartog parece equivocar-se: os nômades são precisamente bons para pensar, para que os gregos pensem a si mesmos. São bons para pensar justamente porque o nomadismoé "impensável" como modo de vida para os gregos. É por isso que os citas estão presentes no senso comum e no pensamento erudito grego.

Quem são os citas para Heródoto? A Cítia ocupa um lugar fundamental em sua imagem do mundo, certamente influenciada por Hipócrates. De certa maneira, os citas já estavam "pré-concebidos" quando ingressaram na História.

Para Hipócrates os habitantes da Europa, do Norte, lugar dos citas, eram selvagens, anti-sociais e irascíveis, resultado de um clima que desfavorecia a agricultura. Tais características, como foi visto, eram as dos seres míticos que se defrontam com Heraclés e outros heróis. Os asiáticos, por sua vez, eram pusilânimes mas dotados de mentes penetrantes. Os gregos, situados entre os dois extremos, reuniam as qualidades de ambos, sem seus defeitos. 
KlaAs Woortmann. O selvagem e a História. Heródoto e a questão do outro

Hipócrates foi, além de médico, geógrafo e para ele as diferenças culturais eram em boa medida devidas ao ambiente físico. $\mathrm{O}$ Norte (aproximadamente a Ucrânia), muito frio, era habitado pelos citas e pelos habitantes do rio Phasis, tornado famoso pela expedição dos Argonautas. O sul, muito quente, corresponde ao Egito e Líbia. A zona temperada corresponde à Ionia. Outra comparação é dada pelo contraste entre Ásia e Europa e nesta última parte do mundo estão incluídos os citas (Glacken, 1967). O contraste é construído para "mostrar como diferem em todos os respeitos, e como as nações de uma diferem inteiramente no físico daquelas da outra" (Hipócrates, Ares, águas e lugares; apud Glacken, ibid.: 85). Entre os dois extremos estava a Ásia Menor, cujo clima temperado era responsável pela maior beleza de seus habitantes: "Ser livre de selvageria é estimulado quando nada é forçadamente predominante, quando prevalesce o equilíbrio em cada aspecto" (ibid., grifos meus). Contudo, Hipócrates não foi um determinista. Para ele, fatores culturais também pesavam (tanto quanto os humores); assim, os Cabeça Longa do Norte exemplificam a herança de características adquiridas pelo costume de alongarem a cabeça desde a infância - o processo se tornaria natural após várias gerações. Por outro lado, o contato cultural provocou o declínio do costume, o que teria resultado numa menor frequiência de cabeças alongadas.

Os asiáticos são pouco corajosos e menos guerreiros que os europeus porque nunca foram sujeitos a mudanças ambientais violentas. Por isso diferem dos europeus, cujo ambiente seria mais propício para forjar o temperamento com paixões ferozes. Contudo, a pusilanimidade dos asiáticos era também devida a instituições sociais, como o despotismo, em contraposição a outros povos (em outros climas), gregos ou não, que viviam em liberdade e que eram, por isso, mais bravos e beligerantes.

Um de seus pontos de vista, exposto em Medicina antiga, é interessante para o contexto deste trabalho: o homem sai da selvageria e atinge a civilização pela domesticação de plantas e animais e pela invenção da comida cozida. Domesticando a natureza, ele se auto-domestica. Como 
já disse, os citas do imaginário grego não praticavam a agricultura; ademais, não comiam pão.

Para Hipócrates os citas eram um povo homogêneo representativo do frio extremo assim como os egípcios representavam o quente e ambos eram afetados pela monotonia do clima: a ausência de variações climáticas sazonais, no Sul como no Norte, trazia consigo similaridades mentais, ainda que invertidas.

O clima também explicava, tanto quanto os costumes, a esterilidade dos homens citas: de um lado, o efeito do frio sobre o corpo; de outro, o hábito da montaria, cavaleiros que eram. Tanto assim que os pobres (e, quem sabe, os escravos) eram menos afetados por tal aflição, já que não tinham cavalos. Possivelmente, Hipócrates estava já construindo uma oposição relativa aos gregos que seria retomada por Heródoto: o hábito da montaria é um hábito de guerreiros nômades, enquanto os gregos eram fundamentalmente hoplitas. A esterilidade das mulheres, por seu turno, era decorrência da umidade de sua carne que provocaria problemas de menstruação, mas também da gordura, que bloquearia o útero. A esterilidade masculina explicaria a existência entre os citas dos enarees, ou anaries, também mencionados por Heródoto (1988: I - 105; IV - 67), efeminados que realizam tarefas femininas. Glacken (1967) sugere que o termo seja o equivalente cita para homossexual.

Em comparação, Políbio foi menos "ambientalista" que Hipócrates e mais "culturalista". Assim, os cynaeteus de sua Arcádia natal, conhecidos pela crueldade e selvageria, contrastavam com outros arcadianos, famosos pela hospitalidade. Mas a selvageria não era devida a fatores ambientais e sim ao abandono de valores e instituições criados pelos arcadianos, em consonância com a natureza. Entre tais valores, destacava-se o cultivo da música. Aqueles selvagens poderiam libertar-se da selvageria pela volta à música.

No entanto, é muito sintomática do ambiente intelectual geral sua conclusão de que o clima tórrido tinha como conseqüência que as espécies nascessem com cabelos lanosos, chifres enrugados, lábios protuberantes, 
KlaAs Woortmann. O selvagem e a História. Heródoto e a questão do outro

narinas largas e extremidades nodosas. Era o caso dos ichthyophagi. Como nota Glacken (1967.: 99), tais qualidades eram tanto de animais como de humanos.

A selvageria poderia, pois, estar relacionada ao ambiente físico.

O ambiente físico também está presente em Heródoto. Combinado com o modo de vida, em boa medida possibilitado pelo ambiente, este último torna os citas inexpugnáveis. O clima da Grécia é o mais belo (pois corresponde ao equilíbrio), enquanto o Egito é quente e úmido e a Cítia fria e seca. O Egito também contrasta com a Grécia por sua abundância de água obtida do rio, que lhes exigia pouco trabalho, enquanto os gregos dependem das chuvas.

A imagem do mundo de Heródoto é uma imagem construída por inversões e contrastes bipolares, tal como em Hipócrates. Esse mundo se organiza segundo um princípio de oposições simétricas relativas a um eixo que atravessa o Mediterrâneo desde as Colunas de Heraclés até o Taurus. Ao norte do eixo, o frio; ao sul, o quente. As especificidades do norte se explicam pelo frio; as do sul, pelo calor. Heródoto exprime bem o modelo fundamental de explicação do mundo dos gregos, organizado em torno às oposições quente/frio e seco/úmido, que compõem também o modelo central da medicina hipocrática. O oposto simétrico da Cítia é o Egito (e a Líbia); o Nilo é para o Sul o que o Istros é para o Norte, correspondendo aos dois trópicos equiidistantes do eixo central.

O princípio da simetria... possui uma capacidade heurística precisa: conhecendo o curso do Istros posso inferir, por analogia, o do Nilo... Assim como o Istros, cuja fonte está entre os celtas, "corta a Europa pelo meio, o Nilo atravessa toda a Líbia e é igual ao Istros". O Nilo e o Istros não apenas estão na mesma latitude, mas se situam sobre o mesmo meridiano: o Istros desemboca em Istria e a Istria está em face (antion) de Sinope. O Nilo desemboca no Egito e o Egito está em face da Cilícia montanhosa ...portanto o delta do Nilo faz face à desembocadura do Istros. (Hartog, 1980: 35)

É esse princípio da simetria que permite ver o Egito e a Cítia, dois de seus principais logos, como iguais invertidos: os egípcios seriam o mais 
antigo dos povos, enquanto os citas se consideram o mais jovem. O norte é lugar de ignorância; o Egito o de uma já antiga ciência. O Nilo marca a fronteira entre a Ásia e a Líbia; a Cítia é um território entre a Ásia e a Europa. Vale notar que para muitos pensadores gregos a Cítia não é nem Europa nem Ásia, e os citas são "gentes entre dois espaços", betwixed and between dois mundos ordenados. Para outros, como Hipócrates, a Cítia está na Europa, mas os citas não são europeus são asiáticos que se deslocaram, e volta-se ao nomadismo, pois para eles inexiste a separação fundamental entre Europa e Ásia.

Antes de Sesostris, o Egito era um território nômade tal como a Cítia. Com Sesostris, o espaço egípcio passa a ser entrecortado de canais e dividido em aldeias e lotes agrícolas, deixando de ser espaço aberto. Esses canais foram construídos com o trabalho de escravos capturados em guerras; os citas também tinham escravos, mas estes eram cegados e usados para ordenhar as éguas. Até os escravos eram invertidos: no sul, dotados de visão, construíam canais de irrigação; no norte, cegos, cuidavam dos animais intrínsecos ao nomadismo. O próprio Heródoto afirma: "é para tal serviço que os citas cegam seus prisioneiros; pois eles não são trabalhadores, mas nômades" (1988: IV - 2).

Antes de Sesostris o Egito era, como a Cítia, um "espaço de percurso", uma imensidão sem divisões; após Sesostris o Egito se assemelha artificialmente, por seus canais, ao que a Cítia é naturalmente, pois esta é um território plano sulcado por rios tão abundantes quanto os canais egípcios. O paradoxo de tal comparação se resolve pela observação de que, enquanto os rios da Cítia favorecem o nomadismo, os canais egípcios impedem a circulação dos cavalos. "Os canais interditam o que os rios permitem e impõem um gênero de vida regido pelo poder do faraó" (Hartog, 1980: 37). Em tudo, pois, o Egito e a Cítia, o Sul e o Norte, o quente e o frio, são equivalentes invertidos.

A Cítia é o oposto de um mundo normal:

Em todos os territórios enumerados acima o inverno é tão rigoroso que durante oito meses do ano o frio é insuportável; naquela região não 
KlaAs Woortmann. O selvagem e a História. Heródoto e a questão do outro

se faz lama derramando água no chão, e sim acendendo o fogo; o mar congela... e os citas... passam por cima do gelo e irrompem com seus carros no território dos sindos. ...[Nos] quatro meses restantes ainda faz frio. Esse inverno é de uma espécie diferente daquele de todas as outras terras; nessa estação, normalmente chuvosa em outras regiões, as chuvas lá são insignificantes, mas durante todo o verão chove ininterruptamente; na época de trovoadas em outras regiões, lá elas não ocorrem... Os cavalos resistem ao inverno cita, mas os mulos e os asnos não podem suportá-lo de forma alguma; em outras regiões, ao contrário, são os cavalos que, expostos ao frio, perecem por causa de uma espécie de gangrena, enquanto os asnos e os mulos o suportam.

Na minha opinião, é também por isso que lá não nascem chifres na espécie de gado chamado mocho. Um verso de Homero serve de confirmação à minha conjectura; ei-lo:

"Na Líbia, onde os cordeiros já nascem com chifres".

Aqui está dito acertadamente que nas regiões quentes os chifres crescem rapidamente, enquanto nas regiões muito frias eles não crescem nos animais de forma alguma, ou crescem muito pouco.

Na Cítia, então, isso acontece por causa do frio. (Heródoto, 1988: IV -28 a 30$)$

Heródoto não explica realmente como chegou à conclusão de que é o frio que faz os bois não terem chifres. Como sugere Darbo-Peschansky,

A questão certamente nasce de uma comparação da Cítia com regiões mais familiares ao investigador: a partir daí ele vê a ausência de chifres dos bois como uma particularidade que merece explicação. A tese é fruto de um "silogismo" no qual ele conjuga uma generalização do tipo "o frio provoca a retração dos tecidos" à informação que detém sobre o rigor do clima cita. O frio provoca a retração dos tecidos, na Cítia faz frio; é então o frio o que, na Cítia, impede os chifres dos bois da espécie mocha de crescerem. (1998:146)

A Cítia se explica, pois, através de um modelo de inversão. Conhecendo o Egito se pode conhecer a Cítia por simetria, invertendo todos os sinais. E vale notar que se os egípcios são bárbaros, são bárbaros “civilizados", enquanto os citas são "selvagens". Um tal modelo que, abstratamente 
concebido, poderia se aproximar da epistéme, parece ter uma função de tornar exótico pelo contraste com "todas as outras terras" cuja metonímia seria a Grécia (equilíbrio entre o frio e o quente; o seco e o úmido).

Qual teria sido a origem dos citas? Heródoto relata vários "mitos de origem" desse povo.

Segundo dizem os citas, eles são o povo mais novo de todos, e sua origem teria sido a seguinte: apareceu naquele território, até então deserto, um homem cujo nome era Targítaos. Os pais desse Targítaos, dizem eles - não creio em sua história, mas eles a contam - teriam sido Zeus e uma filha do rio Borístenes [o hoje chamado Dnieper] ... Durante seu reinado caíram do céu sobre a Cítia alguns objetos de ouro - um arado com o respectivo jugo, um machado de combate e uma taça. Vendoos, o irmão mais velho aproximou-se deles com a intenção de pegá-los, mas o ouro começou a inflamar-se e ele desistiu da tentativa; em seguida o segundo se aproximou, mas aconteceu o mesmo com o ouro; quando os dois se afastaram por causa das chamas do ouro, avançou em terceiro lugar o mais novo; as chamas se extinguiram à sua aproximação, e ele levou consigo os objetos de ouro; diante disso, os irmãos mais velhos concordaram com a entrega total do poder real ao mais novo. (Heródoto, 1988: IV - 5; grifos meus).

Como observa Hartog (1980), o mito legitima a ultimogenitura em contraste com o valor da senioridade na cultura grega. Os três objetos caídos do céu simbolizariam as três funções características do pensamento indo-iraniano: a taça simboliza os cultos; o machado, a guerra; a charrua, a agricultura. Mas surge um problema: como conciliar agricultura com nomadismo?

O próprio Heródoto considera a versão cita de sua origem pouco verossímil. Outra versão é aquela dos helenos do Pontos (1988: IV - 810). Heraclés, conduzindo a manada do monstro Geríon chegou àquela terra, "então deserta mas agora habitada pelos citas". Geríon vivia a oeste do Pontos, "morando na ilha chamada pelos helenos de Erítea, no litoral do Ocêanos... fora das Colunas de Heraclés". Surpreendido pelo intenso frio, Heraclés dormiu e durante seu sono os animais desapareceram. Heraclés encontra, no lugar chamado Hílaia (palavra que tanto significa 
KlaAs Woortmann. O selvagem e a História. Heródoto e a questão do outro

floresta como selvageria), uma jovem mulher-serpente que lhe promete devolvê-los se ele se unir a ela. Dessa união nascerão três filhos, um dos quais, Cites, o mais novo, seria o ancestral de todos os reis citas.

Nessa versão, os três filhos devem realizar uma tarefa "hercúlea", mas só o mais novo é bem sucedido.

O interessante, mostra Hartog (1980), é que Heraclés veio de mais além das Colunas, das bordas do rio Oceano (Okeanós - o invólucro do mundo) onde se localizava a ilha de Geríon, atravessou a Europa, desembarcou na Líbia e construiu as Colunas. Nessa geografia mítica a Eritréia é aproximada da Cítia e, ainda, os espaços marginais da ilha do monstro e da Cítia se comunicam facilmente.

A mulher serpente foi encontrada em Hílaia, a única mancha florestal de toda a Cítia e parece haver nessa versão uma retomada do tema da Mixoparthenos (como a Esfinge), remetendo à Eschidna de Hesíodo com sua morada subterrânea, mãe de vários monstros, alguns dos quais combatidos pelo próprio Heraclés, como a Hydra e o leão de Nemeia. Em Hesíodo, Heraclés mata os três filhos de Eschidna, nem humana mortal nem divina imortal; para os gregos do Ponto, Heraclés dá à mulher monstruosa três filhos. Há aqui uma inversão, por certo relacionada à alteridade cita.

Ser intermediário, meio humana meio animal (além de animal, serpente!), a virgem híbrida do mito heleno é a mãe, se não dos citas, de sua realeza. E o pai é um herói itinerante.

A questão que se coloca é aquela do papel do híbrido. Em outras palavras, dar aos citas uma mãe que não é nem verdadeiramente humana nem verdadeiramente bestial seria uma maneira, para os gregos do Ponto, "pensarem" o nomadismo? Existe uma correlação entre o status de híbrido e o nomadismo? (ibid.: 44)

Se é ou não uma maneira de pensar o nomadismo, é certamente um modo de pensar o selvagem, nunca plenamente humano; sempre entre a natureza e a humanidade. Mary Douglas (1966) concordaria com tal ponto de vista. Por outro lado, se a mãe é um ser monstruoso, por que é o pai 
Heraclés, herói civilizador? Para Hartog a explicação estaria no fato de ser Heraclés ele mesmo um viajante que marca os limites do mundo, tanto quanto defensor da humanidade e fundador de cidades desde a Gália, a Espanha, a Sicília até o Ganges. E exterminador de monstros tanto quanto vencedor de povos bandidos e cruéis. Mas, sempre itinerante, ele não é sempre civilizado; é também marcado pelo excesso de sexualidade e de gula, um libertino, características do homem selvagem (Bartra, 1994). Por vezes um deus-herói, por vezes um herói-besta, sua própria ambigüidade permite aos gregos vê-lo como o pai dos citas. Vale notar também que se os citas, como queria Aristóteles, viviam a seguir suas manadas, Heraclés chegou à Cítia conduzindo a manada do monstro, manada essa reencontrada pela "produção" dos três filhos da mulher-serpente.

Se Heródoto declara explicitamente sua descrença relativamente ao relato das origens dos próprios citas, ele silencia quanto à aceitabilidade da versão helênica do Pontos. É de se notar que essa versão é uma "aplicação local" de um tema mais geral, afirmando a ambigüidade dos citas, e que repete o detalhe dos três irmãos e da ultimogenitura.

O mito heleno da origem dos citas é abundante em ambigüidades, desde os seres monstruosos até a geografia. Esse mito serve, evidentemente, para marcar o afastamento cultural, espacial e temporal dos citas em face dos gregos, já que os citas pertencem ao tempo dos monstros.

Heródoto não afirma descrer da versão dos helenos do Pontos. Mas apresenta uma outra história, "cujo teor me sinto mais inclinado a aceitar", dizele:

...os citas nômades habitantes da Ásia, pressionados pelos massagetas na guerra, fugiram, atravessando o rio Araxes em direção ao território cimério. ...na opinião da maioria [dos cimérios] a única coisa a fazer seria bater em retirada, sem correr os riscos inerentes à resistência em face de um inimigo numeroso; na opinião dos reis, todavia, eles deveriam lutar para defender sua terra [os reis mataram-se uns aos outros, foram sepultados às margens do rio Tiras (hoje chamado Dniester)] e a maioria se retirou... Os citas, quando chegaram, ocuparam um deserto. (1988: IV - 11; grifos meus). 
KlaAs Woortmann. O selvagem e a História. Heródoto e a questão do outro

Portanto, ao relatar a história “mais aceitável", Heródoto também insiste na presença do deserto e no nomadismo. Não deixa de ser estranho que Heródoto considere verossímil que os reis se tenham matado uns aos outros. Por outro lado, segundo Heródoto, os citas haviam invadido a Média, "de fato" tendo permanecido na Ásia durante vinte e oito anos.

Mas quando os citas, após uma ausência de vinte e oito anos, regressaram à sua terra depois de um período de tempo tão longo, lá os esperava outra provação não menos penosa que a guerra contra os medos: encontraram um exército nada pequeno barrando-lhes a passagem. Com efeito, as mulheres citas, diante da ausência prolongada de seus maridos, tinham coabitado com seus escravos.

Havia crescido então uma geração jovem, nascida desses escravos e das mulheres dos citas. Instruídos a respeito de sua origem, eles saíram para enfrentar os citas em seu retorno da Média. (1988: IV - 1,3; grifos meus)

Esse relato é qualificado pelas expressões "de fato" e "com efeito". Heródoto não parece estranhar que toda a parte masculina de um povo tenha se ausentado por tanto tempo. Também não lhe parece estranho que as mulheres tivessem coabitado com escravos. Ora, um tal comportamento seria impensável para um grego, com relação às mulheres gregas; coabitar com escravos seria uma total degradação. Não estaria Heródoto construindo um contraste com as "mulheres de Atenas" que esperam bordando, castas e resignadas, pelo retorno de seus maridos? Ou seria aquele suposto afastamento dos homens uma forma de lidar com a também suposta esterilidade masculina, mal que não afetava os escravos, significativamente cegos? Ou seria uma forma de tornar exóticos os citas pela via de uma suposta sexualidade desregrada?

Outras mulheres, ainda, surgem em Heródoto para construir a alteridade dos citas pelo recurso à selvageria: as já referidas amazonas. Ao contrário de Estrabão e Deodoro, que opõem amazonas a gregos, a narrativa de Heródoto opera com três personagens principais, gregos, citas e amazonas. 
Nesse modelo triangular as amazonas entram para explicar os citas; elas não têm presença por si mesmas mas apenas em função dos citas que, por sua vez, só "existem" em função das guerras médicas, como se verá. Vale ressaltar que, se os citas efetivamente existiram, contrariamente às amazonas, ambos "existiram" no imaginário grego enquanto selvagens e ambos, em conjunto, são usados para pensar a Grécia.

As amazonas estão na origem dos sauromatas, o mais jovem povo cita (Heródoto, 1988: IV - 110 a 117). Depois de guerrear com helenos, isto é, de se relacionarem com os gregos pela guerra, as amazonas se dirigem para a Cítia, entram em combate até que os citas, descobrindo que são mulheres, recusam-se a matá-las. Como nota Hartog (1980), Heródoto parece helenizar o Outro, fazendo com que os citas pensem como se fossem gregos: as mulheres estão excluídas do mundo da guerra e não devem ser mortas. Se os citas são, no plano geral, o inverso dos gregos, neste particular são "helenizados" pelo contraste com outra alteridade, ainda mais radical: as amazonas.

A solução encontrada pelos citas é também uma inversão: em vez de guerrear, casar-se. E para tanto enviam ao encontro das amazonas seus mais jovens rapazes, seus efebos, na interpretação de Hartog (ibid.: 233): "insensivelmente, em face das amazonas, os citas tendem a se transformar em gregos". Ou seja, em face de uma alteridade maior, a alteridade menor é absorvida. Heródoto insiste ainda no fato de que entre os jovens citas e as amazonas teriam se realizado não relações promíscuas, próprias de selvagens, mas casamentos monogâmicos. Vale notar que os citas, quando ameaçados por Dario, procuram - inutilmente - o apoio de outros, inclusive dos andrôfagos (comedores de homens) e dos agatirsos, que "adotam a comunidade de mulheres com o objetivo de, através dessa promiscuidade, [constituir] uma única família" (1988: IV - 104). Se em face dos gregos os citas podiam ser representados como selvagens, nômades do deserto, em face das amazonas eles se tornam quase-gregos.

Daquela união entre as amazonas e os mais jovens rapazes citas, surge o povo sauromata, o "mais jovem dos povos citas", entre os quais as 
KlaAs Woortmann. O selvagem e a História. Heródoto e a questão do outro

mulheres também participam da atividade guerreira. Na narrativa de Heródoto as amazonas primeiro são contrastadas aos gregos, por inversão: elas desconhecem tudo o que os gregos conhecem; num segundo momento elas são relacionadas aos citas e estes, ao longo do texto, vão se tornando quase-gregos. Assim, as amazonas ocupam o lugar do nomadismo, que tornava os citas “impensáveis”, para torná-los compreensíveis; as amazonas "conhecidas" são condição de inteligibilidade dos citas "desconhecidos". Em outras palavras, selvagens imaginários tornam mais familiares outros selvagens, imaginados.

$$
* * *
$$

Contudo, Heródoto procurou relativizar a "selvageria" cita. A Cítia não é toda ela um deserto embora contenha desertos, nem se localiza para além dos últimos homens. Pelo contrário, é bem parte do ecúmeno embora próxima de seu limite e ocupa posição central na imagem do mundo herodotiana.

Os citas não são um povo uniforme, como queria Hipócrates, mas vários povos, alguns dos quais agricultores e a região genericamente chamada pelos gregos de Cítia é habitada também por outros povos, distintos dos citas. Como parte mesmo da inteligibilidade da História e da organização do texto, esses vários povos são organizados num sistema classificatório que guarda analogias com a classificação do espaço: é ao norte que se encontram os desertos, e a selvageria vai crescendo à medida que para lá se avança, à mesma medida que vai diminuindo a humanidade, até se chegar aos grifos e aos arimaspes com pés de cabra. Os citas são, sem dúvida, um povo do Norte mas, para Heródoto, são apenas um dos povos que vivem ao norte, e não se inscrevem entre os mais selvagens, ainda que certamente exóticos.

Os citas são um povo jovem que privilegia a juventude, em contraste com o gregos que privilegiam a senioridade. Contudo, essa juventude só tem sentido em Heródoto por contraste com os egípcios, do Sul, que seriam o mais velho dos povos. 
O nomadismo cita, como ressalta Hartog (1980), ganha um significado todo especial em Heródoto, que o afasta do senso comum grego. Os citas são nômades em contraste com os persas, mas nesse contraste o nomadismo cita deixa de ser uma expressão de selvageria, para se transformar em estratégia. A guerra cita é um combate sem batalhas campais no qual os persas são derrotados, não por nômades, mas por guerrilheiros. Os citas fogem constantemente e os persas os perseguem apenas para serem derrotados. Os citas são hábeis caçadores e mestres no uso do arco-e-flecha; essa maestria é tornada técnica de guerrilha e os persas terminam transformados em caça por aqueles a quem caçavam. É interessante que Heródoto ao descrever a luta utiliza com freqüência termos que descrevem a caça. Há, então, no relato de Heródoto, uma inversão de papéis e o perseguido pelos persas através do território cita é sempre o mestre do jogo.

Por que seria a Cítia inacessível? Menos por sua natureza que pelo "nomadismo" cita.

No contexto das guerras médicas, Heródoto constrói os persas como um exército numericamente poderoso, mas que não sabia guerrear. Não sabiam usar a lança nem o escudo; em suma, não eram hoplitas. Eram um exército sem armas; apenas arqueiros e cavaleiros. Assim, na Grécia, os persas eram bárbaros assemelhados a selvagens. Na Cítia, contudo, são descritos como quase-gregos, quase-hoplitas, que nunca conseguem engajar o inimigo em batalhas campais. Pela lógica do relato, os persas na Cítia deveriam aparecer como bárbaros em face dos quase-atenienses. No entanto, a cavalaria persa sempre se amedronta quando enfrenta a cavalaria cita; em contraste, são os citas que fogem quando se defrontam com a infantaria persa.

O grande contraste elaborado por Heródoto é aquele entre o essencialmente cavaleiro (cita) e o essencialmente infante. Ante o espartano, o persa é o cavaleiro temível (mas que não sabe, realmente, combater), mas ante o cita ele é transformado no infante que nunca consegue conquistar um território abandonado por efeito do nomadismo. Na Grécia os persas 
KlaAs Woortmann. O selvagem e a História. Heródoto e a questão do outro

são arqueiros e cavaleiros; na Cítia, arqueiros e cavaleiros são os citas. Por que, indaga Hartog (1980), essa inversão?

Para Heródoto, Dario invade a Cítia para forçar o inimigo a apresentarse em batalha campal. Em face da recusa, Dario teria interpelado o rei cita: se este se considera capaz de enfrentá-lo, que ofereça batalha; se não se considera capaz, então que se submeta. Segundo a interpretação de Heródoto, Dario não imaginaria a possibilidade de uma terceira alternativa. Dario, então, pensaria como um grego e veria a Cítia como uma cidade grega. Ele não seria capaz de entender os citas, que "pilham" seu próprio território à medida que "fogem" como técnica de combate, destruindo fontes de água e pastagens depois de terem levado suas famílias e seu gado para refúgios longínquos.

...é precisamente na medida em que Heródoto mostra Dario sob os traços de um estrategista tradicional que ele pode fazer surgir a alteridade da estratégia cita: era necessário vestir Dario com as roupas de um hoplita para permitir que os arqueiros citas galopassem... (ibid.: 68)

E o autor prossegue, ressaltando

...a aparente incapacidade do relato herodotiano de operar um modelo que comporte três termos: os gregos, os persas, os citas. Quando confrontados aos gregos, os persas são, com efeito, "persas", isto é, gente que não sabe combater, anti-hoplitas; mas em face dos citas... eles aparecem como quase-hoplitas, isto é, como "gregos". Do ponto de vista estratégico, o relato retém apenas dois termos: gregos/persas na Grécia e, na Cítia, citas/persas "gregos"; gregos e anti-hoplitas de um lado; citas e quase-hoplitas de outro. Se na Cítia os persas se tornam "gregos", poder-se-ia pensar que, pela permutação de papéis, os citas aparecessem como persas, isto é, como anti-hoplitas. De fato, são eles os arqueiros e cavaleiros, portanto os mais afastados do combate hoplita. Mas, em nenhum momento Heródoto faz supor que eles não sabem combater: sua estratégia é, pelo contrário, qualificada como a mais inteligente; ademais, eles não podem aparecer com anti-hoplitas, pois são eles que, afinal, têm a vantagem e obrigam os persas a bater em retirada. (ibid.) 
Os citas ganham a guerra fugindo. E Heródoto relata que, quando da iminência da invasão de Xerxes, a Pítia aconselha os gregos a fugirem para o extremo (escathiá) da terra. Isto é, os gregos deveriam adotar uma estratégia cita, o que teria sido interpretado por Temístocles como deixar a cidade e recorrer ao combate naval, tornado equivalente à guerrilha cita. Em ambos os casos, procura-se sempre escapar, ser áporos.

É significativo, também, que o efebo ateniense fosse chamado "cita", por ser o "hóspede dos fortins da fronteira", o perípolos, "aquele que percorre os eschatiá, tal como o cita é o hóspede dos confins do mundo" (Hartog, 1980: 72).

O nomadismo cita em Heródoto ganha então outro significado. Para ele, a nação cita teria desenvolvido a mais sábia das soluções, pois um povo sem cidades, um povo de arqueiros à cavalo, que não vive da agricultura mas de seu gado e cujas habitações são as carroças, é um povo que não pode ser combatido e derrotado.

O relato de Heródoto é um tanto contraditório: por um lado, os citas são tornados, pelos constrangimentos narrativos, em quase-atenienses; no entanto, as exigências etnográficas os empurram na direção contrária: são nômades, ápoleis e, assim, o inverso dos gregos. Para Heródoto, então, o nomadismo é uma questão mais complicada. É por certo um tropo na retórica do exotismo e na História existem muitos nômades, na Î́ndia, na Líbia e em outros lugares. São nômades desde povos reais até povos imaginários, como os andrófagos. Todos têm em comum a ignorância da agricultura, mas as diferenças culturais entre os vários povos nômades são muito grandes e os citas não são, dentre os nômades, aqueles que apresentam a maior carga de alteridade, talvez como resultado das exigências narrativas nas quais os citas são sempre os mediadores temáticos entre gregos e persas.

Os citas não são sempre nômades; também há os que cultivam o trigo e, do ponto de vista político, existem vários citas distintos. Assim existem os citas "reais" (súditos de um rei), que consideram todos os demais como escravos. O texto em conjunto parece contraditório, pois às vezes os citas 
KlaAs Woortmann. O selvagem e a História. Heródoto e a questão do outro

são todos eles nômades, às vezes não. As observações etnográficas por vezes conflitam com as exigências narrativas centradas, no que respeita aos citas, na expedição de Dario. A guerra cita deve ser homóloga, na narrativa, à guerra com Xerxes e nessa narrativa os citas são tornados quase-atenienses. Mas, ao mesmo tempo, devem ser o oposto dos atenienses. Os citas devem vencer a guerra, mesmo porque, para os gregos, não se passa impunemente da Ásia para a Europa; mas não poderiam fazêlo pela batalha campal, hipótese absurda; devem vencê-la pela aporia que os torna inexpugnáveis (além de exóticos). A aporia é sua fortaleza, tanto quanto a frota naval foi a fortaleza dos gregos, mas a mesma aporia é atributo de nômades.

O nomadismo é, então, o resultado de uma reapreensão do senso comum em função dos constrangimentos da guerra na estrutura narrativa da História: se ele é um modo de vida - e aqui Heródoto não se afasta do senso comum - é também uma estratégia e é ela que lhe dá inteligibilidade no relato.

Certas ambigüidades, contudo, persistem: como podem os citas ser, ao mesmo tempo, nômades e súditos de um rei? Até certo ponto, ao que parece, a contradição resulta do rótulo de bárbaros. Todos os bárbaros têm um rei despótico, e os citas são bárbaros; mas um poder real despótico nômade é impensável - mesmo porque os citas, no senso comum grego, são "mais que bárbaros”, são selvagens.

Em História (IV- 62,66) é dito que a Cítia não é um espaço indiferenciado, mas um território dividido em nomos governados por nomarcas. O termo "nomos" é o mesmo empregado para descrever a divisão administrativa do Egito e da Pérsia, ambos sedentários. Egípcios e persas são governados por um poder despótico, sendo, portanto, bárbaros; os citas são ao mesmo tempo nômades e têm também divisões administrativas e um rei despótico. Heródoto resolve o paradoxo pelo significado das sepulturas reais. As sepulturas se localizam nos confins do território (e os citas, lembremos, são o povo dos confins do mundo) e cada sepultura é um centro do território; um centro "descentrado" que "opera" 
o nomadismo. Para conquistar o território, deveriam os persas encontrar as sepulturas, o que lhes é interditado pela guerra de guerrilha. Dirigindose aos persas o rei cita, Idanthyrse, procura fazê-los ver que sua maneira de guerrear não é irracional. Mas,

fazendo Idanthyrse falar, o narrador se dirige aos persas que, na Cítia se comportam como gregos e são quase-hoplitas, mas, também e sobretudo, ao destinatário [o ouvinte grego]. E é precisamente neste ponto, na transcrição do nomadismo em termos estratégicos, que se situa a grande originalidade de Heródoto; o nomadismo é finalmente pensável, de maneira positiva, como estratégia. Ele é o único a propor essa reflexão teórica que não será verdadeiramente retomada depois dele; o nomadismo continuaria a ser definido em termos apenas negativos. (Hartog, 1980: 215; grifos meus)

Quando Dario atravessou o Istros (Danúbio), essa expedição teria sido a primeira vez que um rei da Ásia atravessa os limites com a Europa, prefigurando a guerra de Xerxes contra os gregos.

O texto de Heródoto é construído pela via, não só de analogias, mas também de homologias entre Dario em face dos citas e Xerxes em face dos gregos; os incidentes relativos ao segundo são como replicações do primeiro. É uma mesma estrutura que se repete, à maneira dos mitos, embora se trate de um relato histórico. É nesse jogo que os citas podem ser tornados quase-gregos.

No mesmo texto, até povos selvagens fabulosos, como os andrôfagos canibais desprovidos de diké e de nómos, cuja aliança teria sido buscada pelos citas, comparecem em nome da diké, numa relação homóloga àquela ocupada por Creta, Siracusa, Argos e outros na busca de alianças por parte dos atenienses. Permanece, contudo, o paradoxo: os reis citas (reis nômades?) são déspotas tanto quanto Dario, e não poderiam ser combatentes em defesa da liberdade como teriam sido os atenienses.

A relação Sul-Norte, já referida, mas agora acrescida do componente limite-do-mundo, também surge no contexto da guerra dos persas contra os citas. Ctésias diz que Dario após ter atravessado o Istros penetrou na 
KlaAs Woortmann. O selvagem e a História. Heródoto e a questão do outro

Cítia durante quinze dias, até que o rei cita lhe ofertou um arco. Como o arco cita era mais robusto que o persa, Dario decidiu fugir. É o mesmo tema do arco que o inimigo não consegue vergar, referido por Heródoto com relação aos etíopes do Sul em face de Cambises:

Ctésias portanto transferiu para os citas o que Heródoto atribuiu aos etíopes, como se os elementos que pertencem à figura das gentes dos confins fossem perfeitamente intercambiáveis; o arco podia facilmente viajar do extremo sul ao extremo norte. Ademais, a Cítia e a Etiópia são, uma e outra, "espaços inacessíveis". (Hartog, 1980: 63)

Permito-me, aqui, um breve parênteses. O tema do arco e, portanto do arqueiro, é trabalhado de forma muito interessante por Le Goff \& VidalNaquet (1979) com relação ao "cavaleiro selvagem” do imaginário medieval (do qual me ocuparei em um trabalho próximo). O uso do arco nesse imaginário é claramente relacionado à selvageria silvática e à felonia, $\mathrm{e}$ floresta equivale ao deserto. Lembremos, por outro lado, que Heraclés é o criador dos citas em certas versões helênicas e que tal criação, como foi visto, se deu em circunstâncias de notável ambigüidade. Le Goff \& VidalNaquet nos dizem o seguinte:

Houve um tempo, muito afastado do século XII, que conheceu também uma oposição entre o guerreiro equipado e o arqueiro isolado, selvagem. Tal foi o caso da Grécia arcaica e clássica. Assim, o rei de Argos, numa peça de Eurípides, desqualifica, em nome das virtudes do hoplita, o arqueiro Heraclés "homem de nada que adquiriu uma aparência de bravura em seus combates com as bestas e foi incapaz de qualquer outra proeza. Ele jamais portou um escudo em seu braço esquerdo nem afrontou uma lança: portando o arco, a arma mais imperfeita, ele estava sempre prestes a fugir. Para um guerreiro, a prova da bravura não é atirar com o arco; ela consiste em manter seu posto e ver, sem baixar ou desviar o olhar, avançar sobre ele todo um campo de lanças erguidas, sempre firme em sua posição". De Homero ao fim do século V, o arco é a arma dos bastardos, dos traidores (como os teucros e pandaros na Ilíada), dos estrangeiros (como os citas em face de Atenas), em suma, dos subguerreiros... (1979: 274; grifos meus) 
Le Goff \& Vidal-Naquet percebem uma curiosa semelhança entre o arqueiro Heraclés e Orlando Furioso. Ressaltam ainda que o arco (e junto com ele o caçador), legítimo na floresta, é desleal em combate aberto no contexto da cavalaria. Esse contexto é, evidentemente, o da civilização. E notam ainda que os romans courtois assimilam a figura do arqueiro àquela do homem selvagem, de alguma maneira associado ao signo zodiacal do Sagitário, um centauro.

Retornando a Heródoto, qual, então, o significado dos citas em seu texto?

Eles são, fundamentalmente, um recurso narrativo e como tal são bons para pensar a relação entre gregos e persas. Selvagens mais que bárbaros, são os mediadores cuja alteridade permite o relato que opõe persas a gregos. Mas essa alteridade é manipulável nos diferentes contextos narrativos da História. No texto de Heródoto os citas exercem um papel fundamental como condição da inteligibilidade da guerra entre gregos e Xerxes. Se os citas ocupam uma posição destacada nesse texto, a razão está no fato de terem sido guerreados sem sucesso por Dario. São as guerras médicas que constituem a matriz de seu relato e são elas que fornecem o modelo de inteligibilidade dos citas. De certa maneira, os citas de Heródoto não existiriam sem a expedição de Xerxes contra os gregos. Poder-se-ia talvez dizer que, mais que um povo em si, objeto de uma etnografia, os citas foram para Heródoto um recurso heurístico.

Hartog (1980) afirma que Heródoto não era capaz de tratar de gregos, persas e citas num mesmo discurso. A estrutura da narrativa é bipolar: citas em oposição a persas; citas em oposição a gregos; gregos em oposição a persas. Por outro lado, para ressaltar a alteridade cita, os persas são transformados em gregos. $O$ texto sobre as amazonas também começa "triangular": gregos, citas e amazonas. Mas, para ressaltar a alteridade das amazonas, os citas são transformados em gregos: eles pensam como gregos (não se deve matar mulheres) e adotam a mesma polaridade grega que opõe a guerra ao casamento. 
KlaAs Woortmann. O selvagem e a História. Heródoto e a questão do outro

No entanto, se é correto que Heródoto opera, em cada momento particular, por meio da regra do "terceiro excluído", no conjunto da História, os citas são sempre um terceiro que torna possível falar dos persas e torná-los inteligíveis em face dos gregos, o terceiro que possibilita a construção de identidades contrastivas. O texto, tomado como um todo, é construído para opor gregos a persas (civilizados a bárbaros) e nele os citas comparecem exercendo o papel de mediador da oposição. Vale notar que a oposição Sul-Norte, citas-egípcios, é também triangular, visto que serve essencialmente para falar dos gregos.

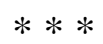

Heródoto foi um autor ambíguo. Se fez uma etnografia, foi sempre uma etnografia ateniense. Contudo, embora o ambiente intelectual de sua época favorecesse as especulações sobre a origem da humanidade, com uma Idade de Ouro e com teorias genéticas, ele se ocupou principalmente com os costumes correntes de sociedades existentes, seja como testemunha ocular ou por meio de relatos orais, segundo o que ele chamou de historié, literalmente "seguir a pista de algo". Ao mesmo tempo, porém, descreveu povos imaginados.

Uma das maneiras de construir diferenças significativas de alteridade éa retórica da inversão, utilizada por Heródoto. Assim os egípcios com um clima outro e um rio diferente também adotaram costumes ao inverso, não só dos citas, mas de todos os outros homens e "todos os outros homens" significa sobretudo os gregos, que equivalem à humanidade plena.

Sua teoria climática opera, por certo, através da inversão e da oposição polar entre quente e frio. Assim os egípcios são o inverso dos citas. Mas todos os Outros são o inverso dos gregos e, como observa Hartog (1980), se os costumes de todos eles fossem o inverso dos costumes gregos, no final das contas, todos os Outros teriam os mesmos costumes. No entanto, em Heródoto, se a inversão constrói a alteridade, cada um é o inverso à sua própria maneira e a diferença, portanto, não se restringe à inversão. 
A etnografia de Heródoto é mais rica que a simples inversão; se esta é utilizada para iniciar a descrição de um costume, como argumento de verossimilhança, a descrição prossegue de forma independente da figura retórica da inversão.

Heródoto era capaz de distinguir culturalmente vários grupos bárbaros ou selvagens, como os "trogloditas" da Etiópia, os "nômades" citas, outros povos "canibais" etc. Para ele o bárbaro ou o selvagem não era um ser à parte, mas um membro da família humana que merecia o estudo não só de trivialidades curiosas mas também dos padrões de casamento, hábitos alimentares e outros costumes.

É verdade que Heródoto privilegiou as culturas que mais importavam para a Grécia, como persas e egípcios. Se não deixou de lado outros povos, como os citas, os selvagens por excelência da Antigüidade, estes ingressam em sua narrativa, como já dito acima, como recurso retórico. No entanto, sugere Hogden (1964), com relação aos povos descritos, todas as descrições partiam de critérios que lembram uma noção de cultura capaz de individualizar cada sociedade: descendência comum, idioma comum, religião comum, hábitos alimentares, de vestuário etc. Heródoto enfatizava aqueles padrões que mais tarde se tornariam os temas clássicos da antropologia: formas de casamento, ritos religiosos, ritos funerários etc. $\mathrm{O}$ patriarcado era-lhe de grande interesse, já que bem perto da Grécia, a Lícia era habitada por um povo de descendência matrilinear. Outros costumes distintos dos gregos igualmente estimulavam sua curiosidade comparativa, como a "compra da noiva" na Trácia. Suas descrições de instituições matrimoniais eram bastante completas e "tomadas em conjunto, formam uma série da promiscuidade até a monogamia patriarcal" (ibid.: 24). Embora ele não estivesse preocupado com questões de gênese, sua série lembra de perto aquelas dos "evolucionistas" do século XIX. Mas, é preciso ressaltar, a "promiscuidade" de Heródoto era tão imaginária quanto aquela dos novecentistas.

A comparação entre culturas foi um dos pontos centrais da etnografia de Heródoto, sem os problemas que iriam mais tarde afligir os teólogos- 
KlaAs Woortmann. O selvagem e a História. Heródoto e a questão do outro

historiadores medievais, obrigados a conciliar a diversidade cultural com os supostos de uma homogeneidade primordial e de uma prioridade histórica da tradição judaico-cristã. Tampouco se colocava para ele o problema dos filósofos-cientistas dos séculos XVIII e XIX quanto à construção de sucessões evolutivas a partir de similaridades culturais.

Ele não expressou qualquer desejo de conferir à sua própria cultura a honra de ter sido a fonte ou o pináculo da conquista cultural. Na verdade, as similaridades eram mencionadas com a intenção mais modesta e madura de demonstrar contatos históricos anteriores, a transmissão da cultura de grupo para grupo, a operação de um processo de difusão; ou de interpretar a própria cultura grega como um amálgama de dádivas vindas de diferentes doadores. Aparentemente, na Grécia do século V não havia nem honra nem desonra no cultuar divindades vindas de outras culturas ou praticar costumes tomados de empréstimo. A semelhança como resultado do empréstimo era reconhecida como o resultado inevitável e comum da migração e da mistura de povos. (Hogden, 1964: 26)

Se o juízo de Hogden sobre Heródoto é correto, sua insistência num cosmopolitismo relativista grego me parece exagerado: o século V "século de Péricles" - foi o século da migração do selvagem da mitologia para a história/etnografia; de um mundo fora do tempo e do espaço para o tempo/espaço do encontro com outros povos. E, lembro novamente, Heródoto se deteve no exame do particular de cada povo, não obstante suas ambigüidades e seu recurso à geografia hipocrática.

Para o pensamento grego, como foi dito, havia uma oposição entre cosmos e caos, entre cidade e fora-da-cidade. Havia, por outro lado, uma associação entre o selvagem e o homem monstruoso. A suposta mudez de alguns povos poderia indicar um estado/estágio selvagem; alguém ininteligível, sem a linguagem que caracteriza a humanidade plena. Se bárbaro e selvagem não eram categorias intercambiáveis, em ocasiões de crise, uma "selvageria" podia ser atribuída a quem ameaçava a cidade grega e tivesse valores diferentes dos gregos. Mas em geral, havia uma distinção entre bárbaro e selvagem e, como disse, podia tratar-se mais de uma questão de estágios. Lembremos o contraste feito por Heródoto entre o 
Egito, lugar de ciência, sofisticação e agricultura, e a Cítia, lugar de ignorância e nomadismo.

Para alguns pensadores gregos, ninguém que vivesse fora da cidade possuía uma humanidade plena, visto que vivia uma vida sem lei. Para outros, a distinção entre bárbaro e selvagem era aquela entre quem seguia alguma lei, mesmo que não a dos gregos, e quem não seguia lei alguma. Havia uma gradação entre o selvagem, quase animal, e o bárbaro, quase humano. Existiam, pois, pontos de vista conflitantes: para Aristóteles os bárbaros eram fora-da-lei naturais, essencialmente escravos; seria justo escravizá-los pois não tinham lei. Para outros, os bárbaros, embora escravizáveis, possuíam alguma lei, ainda que não formalizada, notadamente regras de parentesco. O nomadismo, a ausência de agricultura e um suposto "comer cru" eram, contudo, sinais de selvageria. E não devemos esquecer que centauros ou cíclopes podiam ser usados como metáforas de bárbaros e de selvagens.

Para Heródoto, ao contrário, todos eram humanos e portanto merecedores da curiosidade histórico/etnográfica. Contudo, seu estudo das religiões o traía como grego, como afirma Ariès (1989), o que contradiz o "otimismo retrospectivo" de Hogden (1964). Para o estudioso que crê, só pode haver um panteão de divindades; reconhecer a presença de outras divindades com outros nomes em cada povo sucessivamente estudado, abalaria o próprio fundamento da religião do observador, sugere o mesmo Ariès. Heródoto parece ter adotado a solução que seria tantas vezes adotada mais tarde, inclusive com relação aos ameríndios: a equivalência dos deuses - os nomes diferiam, mas as divindades eram as mesmas; Zeus era Zeus em todos os lugares, ainda que com outros nomes. Assim a religião egípcia foi por ele "vestida à moda grega" (Ariès, ibid.: 93) e as divindades egípcias transmutadas nas divindades gregas; para Heródoto, Osiris é Dionísio. Outras vezes nem tradução há: os líbios adoram Atena, Zeus, Poseidon etc., sem que se saiba qual o nome em língua líbia. O hábito permaneceu e todos nós aprendemos que no Brasil "os índios chamavam Deus de Tupã”. 
KlaAs Woortmann. O selvagem e a História. Heródoto e a questão do outro

Há, todavia, outra interpretação para a helenização das divindades de outros povos:

Ele [Heródoto] não abandona as suas referências gregas nem mesmo ao falar sobre o Egito... Sinal de que a maioria das tradições religiosas dos gregos foram importadas do Egito, como sustenta categoricamente Heródoto? Maneira de explicar o desconhecido pelo conhecido, mediante um sistema de equivalências onomásticas e de analogias entre os cultos das diversas terras evocadas e os cultos gregos? (Darbo-Peschansky, 1998:45)

No entanto, como indicador de uma certa inferioridade, os bárbaros parecem sempre adorar menos deuses que os gregos: os massagetas, por exemplo, adoram apenas ao Sol e os citas têm apenas oito divindades.

Se a alteridade deve ser afirmada, em certos momentos, ela deve sê-lo segundo modelos gregos. Lembro a versão helênica da origem dos citas, atribuída a Heraclés e não explicitamente rejeitada por Heródoto. De fato, ao descrever as maravilhas do território cita, ele se refere a uma pegada enorme impressa no chão, que seria a pegada de Heraclés. Como afirma Hartog, os gregos possuíam

...um estoque de personagens disponíveis prontos a responder a todas as situações; presentes como operadores de inteligibilidade, eles servem para classificar, para ordenar os fenômenos; eles ajudam a pensar o mundo... como instrumentos lógicos. (Hartog, 1980: 247)

E, poder-se-ia acrescentar, a pensar o mundo helenicamente. Se Heraclés é o demiurgo que fez surgir os ambíguos citas, ele é também "criador" dos gregos. A pegada de Heraclés remete ao fato de que Heródoto não escapa da tentação de relatar "maravilhas". Não seria descabido supor que descrever as "maravilhas" de um lugaré uma forma de construir a alteridade exótica dos habitantes desse lugar, alteridade que pode ser dada pelo "outro lado" do herói civilizador, como já vimos.

Então, se Heródoto destacava a particularidade, termina por abandonála quando o tema é o ser essencial do homem, e esse ser é helenizado. 
Com relação ao Egito e à Grécia, ele não imagina que possam haver entre os dois diferenças fundamentais de civilização. Por outro lado, não percebe diferença alguma no tempo; os vários milênios são como que fundidos num tempo imóvel.

Seria certamente exagerado afirmar que Heródoto "possui ... o sentido certeiro da particularidade que é propriamente o sentido moderno da história", como quer Ariès (1989: 92). A fusão de tempos e a helenização de outras religiões, ressaltadas pelo próprio Ariès, não parecem confirmar tal julgamento.

Não obstante, a diferença o impressiona (Thomas, 1971) e apesar de suas limitações é importante notar que

Os resultados das investigações de Heródoto de Halicarnassos são apresentados aqui, para que a memória dos acontecimentos não se apague entre os homens com o passar do tempo, e para que feitos maravilhosos e admiráveis dos helenos $e$ dos bárbaros não deixem de ser lembrados, inclusive as razões pelas quais eles guerrearam. (Heródoto, 1988: I - 1; grifos meus).

Assim ele é exemplar da curiosidade ocidental que iria muito mais tarde desembocar na antropologia. E Ariès termina por ter razão quando observa que Heródoto, sempre observando o estranho, "sabe ressaltar... as coisas que o surpreendem, isto é, as que marcam uma diferença entre os modos de vida do lugar que visita e os hábitos de sua raça" (ibid.: 92).

A comparação servia-lhe para construir um certo relativismo, como no trecho da História a seguir, na qual ele critica Cambises por ridicularizar crenças e práticas religiosas de outros povos:

Parece-me absolutamente evidente que Cambises era muito louco; se não o fosse, ele nunca se teria dedicado a ridicularizar as coisas sagradas e as instituições alheias. Com efeito, se se propusesse a todos os homens a escolha das melhores instituições entre todas as adotadas, cada um, depois de pensar no assunto, indicaria as de sua própria terra - tão convictos estão todos de que suas próprias instituições são as melhores, e muito. Não é normal, então, a não ser para um louco, querer 
KlaAs Woortmann. O selvagem e a História. Heródoto e a questão do outro

ridicularizar essas coisas. Há muitas provas de que todos os homens têm esse sentimento a respeito de suas instituições; uma delas é a seguinte: quando Dareios era rei convocou os helenos presentes onde ele estava e lhes perguntou quanto deveria pagar-lhes para consentirem em comer seus próprios pais por ocasião da morte destes; eles responderam que não fariam isso por dinheiro algum. Em seguida Dareios convocou os indianos chamados calários, que comiam seus pais, e lhes perguntou na presença dos helenos (eles estavam a par da conversa através de um intérprete) quanto teria de pagar-lhes para consentirem em incinerar numa pira os seus pais depois de mortos. Os indianos lhe pediram aos gritos para não pronunciar palavras de mau agouro. Eis aí a força das instituições, e Píndaro, em minha opinião, estava muito certo quando disse em seu poema que o costume é o rei de todos. (1988: III - 38)

Para Rowe (1965), o trecho acima expressaria o estranhamento de Heródoto da própria cultura grega. Para ele, ainda, Heródoto teria aprendido a apreciar a alteridade com os persas, aparentemente mais relativistas que os gregos. A conclusão de Rowe, contudo, pode ser incorreta. Por um lado, Rowe sustenta sua afirmação na transcrição incompleta do trecho, não deixando perceber que era uma crítica a Cambises. Por outro lado, como mostra Hartog (1980), esse trecho é parte do jogo de inversões já referido, que não é uma forma de projetar a dúvida, como na construção: se duas condutas inversas são, em seus respectivos lugares, justas, então ou tudo é justo ou nada é justo. A inversão é uma forma de afirmar a diferença, mais do que de compreendê-la, e no jogo de inversões os gregos sempre ocupam a posição de equilíbrio. Heródoto nunca deixou de ser grego, como deixa muito claro todo o seu discurso sobre os citas.

É preciso notar também que Heródoto só falava grego e provavelmente não visitou nenhum país mais demoradamente. Como diz Momigliano (1975: 12), não existia uma tradição de tradução na Grécia nem qualquer interesse em aprender outras línguas; o olhar que Heródoto lança sobre o Outro é um olhar "frio e seguro de si mesmo".

Operando através de intérpretes, suas traduções são freqüentemente duvidosas. Assim diz ele que as amazonas são chamadas pelos citas de 
Oiórpata, termo que traduz para o grego como "matadoras de homens". Ou seria uma tradução para o cita da expressão homérica Anti-ánerai, "inimigas dos machos"? Por outro lado, se "amazonas" (a-mazós - sem seios) se traduz por Oiórpata, as etimologias são inteiramente distintas.

O humanismo universal de Heródotoé paradoxal: se ele permite relativizar sua própria cultura ante à diversidade (admitindo-se a interpretação de Rowe (1965)), não lhe permite compreender a alteridade em seus próprios termos. E a fusão de tempos fez dele um historiador atemporal. Deste ponto de vista, ironicamente, o "pai da história" era anti-histórico. Note-se que os gregos, tanto quanto os romanos, não pareciam sensíveis às diferenças no tempo, como também não o foram com relação às diferenças no espaço. O único tempo percebido como radicalmente distinto era o tempo mítico (ibid.) e características de um povo eram facilmente atribuídas a outro, muito distante do primeiro.

Se Heródoto estava preocupado com um tema central do pensamento ocidental - a unidade da humanidade -, isso fez com que a particularidade resvalasse para o anedótico ou para o exemplo que serve como lição de moral.

...Alguns fatos e alguns heróis... emergem de uma espécie de obscuridade, do nada, sem indicação de data ou lugar. Estes casos exemplares são destacados do tempo... porque ilustram uma constante da natureza humana. (Ariès, 1989: 93)

Heródoto era, pois, bastante ambíguo. De um lado, em contraste com autores posteriores que formaram o imaginário "etnográfico" medieval, ele se revelava cético; se seu dever era relatar o que lhe foi dito, não se sentia obrigado a acreditar em tudo. No entanto, parecia aceitar a existência de homens com um só olho na China, visto que aceitava a possibilidade de que as partes mais remotas do mundo incluíssem fenômenos maravilhosos. Assim, sucumbindo ao exotismo, à medida que aumentava a distância, os seres humanos se tornavam mais estranhos. Mais além dos issedonos, "morariam os arimaspos de um olho só, depois dos quais morariam os grifos guardiães 
KlaAs Woortmann. O selvagem e a História. Heródoto e a questão do outro

do ouro" (Heródoto, 1988: IV - 13). É verdade que Heródoto está aqui repetindo um poema épico de Aristeas. Mas seu texto não deixa de ser ambíguo, pois ele afirma que: "De nossa parte, vamos reproduzir todas as informações obtidas por ouvir dizer em termos de relatos precisos, expondo todos os dados possíveis a propósito das regiões mais remotas" (ibid.: IV - 6). Em contraposição, afirma que numa região remota "as montanhas são habitadas por homens com pés de cabra, e que ainda mais longe de tais homens há outros que dormem durante metade do ano" (ibid.: IV - 25).

Ele se revela claramente cético quanto a tais afirmações, mas podemos perguntar por que, então, incluiu tais seres em seu relato? Se se trata de "informações" colhidas de outros povos (entre os quais os citas), não seria uma forma indireta de tornar exóticos tais povos, atribuindo-lhes a crença em seres teratológicos? De outro lado, o fantástico pode ser um recurso retórico para captar a atenção de seu público para um texto que gira basicamente em torno das guerras médicas. Infelizmente, o que ficou para a posteridade medieval e mesmo renascentista foi o fantástico.

Apesar de seu ceticismo, o fantástico, uma das dimensões do selvagem, seria plausível no mais distante, uma atitude mental não muito diferente daquela de Colombo, muitos séculos mais tarde: os ameríndios que viu eram seres humanos normais e simpáticos, mas em ilhas remotas, ainda não exploradas, existiria seres teratológicos. O exótico, em sua forma mais extrema, é sempre empurrado para a fronteira do contato imediato.

A História de Heródoto terminou então indo para mais além dos limites da historié e não deixou de incluir povos selvagens/monstruosos. Volto então à idéia grega de selvagem.

Para os gregos antigos, como disse, selvagem não significava necessariamente bárbaro. Para Aristóteles o bárbaro não tinha acesso à razão, logos, porque não vivia em cidade e um dos atributos possíveis do selvagem era justamente a ausência de razão. Mas tal ausência podia ser circunstancial: passando a viver na pólis, tornar-se-ia civilizado. Por outro lado, existiam os "naturalmente inferiores"; haveria então uma dimensão cultural/histórica e outra, natural. 
Os atributos do selvagem, ausência de linguagem e crueldade, podiam ser, em certas circunstâncias, aplicados a bárbaros, especialmente com o medo após as guerras. Mais que os bárbaros, os selvagens se opunham à idéia de pólis e hemeros, a sociedade governada por leis justas. Se, como disse Bartra (1994), o selvagem teve de ser inventado antes de ser encontrado, ele terminou transpondo os limites do domínio da mitologia para entrar no espaço da geografia. Como disse antes, combates com centauros eram metáforas de combates com bárbaros. As características de seres fabulosos, cuja existência era admitida, foram projetadas sobre povos conhecidos ( germânicos, etíopes, citas etc) ou imaginados, desprovidos de civilização. Assim uma "imaginação mitológica" engendrou uma "imaginação etnográfica".

Contudo, os gregos reconheciam também em si mesmos elementos de uma selvageria expressa na mitologia, mas domesticada pela pólis. E também os patrícios romanos, como mostra Coulanges (1981), percebiam a plebe como selvagem; Tito Livio os via como "sem família": sem culto doméstico e sem antepassados. Deles se dizia: connubia promiscua habent more ferarum.

A idéia de selvagem incluía, como foi visto, desde seres violentos e cruéis até outros, sábios e justos, e é interessante observar que Sócrates era comparado a um silenus, ser bestial mas capaz de decifrar os segredos do mundo. Incluía também ninfas idílicas: Chiros, o centauro que transmitiu a imortalidade a Prometeu, tinha por esposa uma ninfa; Pholus era filho de um silenus e de uma ninfa.

Não me interessa aqui a descrição de todas as variedades de seres bestiais, entre o animal e o humano. Oque importa é que o selvagem servia para marcar a identidade civilizada pela construção de uma alteridade radical. O grego civilizado é uma entidade essencial, idêntico apenas a si mesmo (Bartra, ibid.: 31). Por isso mesmo, o selvagem mítico/etnográfico ou o bárbaro "selvagizado" devia permanecer como o exótico radical não compreendido, o que de resto era garantido pela própria noção dominante de história que negava sentido ao evento e ao particular. 
KlaAs Woortmann. O selvagem e a História. Heródoto e a questão do outro

Vale lembrar ainda que para os gregos os homens monstruosos podiam se tornar um tema de estudos porque o próprio mundo mitológico grego era cheio de seres resultantes da união entre deuses e humanos e entre humanos e animais. Se os próprios deuses conspurcavam, podia-se olhar com certa naturalidade para centauros, para o Minotauro e outros seres que tanto podiam habitar lugares aprazíveis, como prados e lagos, quanto o deserto ou o Labirinto, arquétipo da cidade selvagem (White, 1994).

Heródoto movia-se, então, num espaço intelectual que fundia, por necessidade, mitologia com etnografia. Não se pode esquecer que sua História foi a construção de uma identidade grega e nessa construção o selvagem mitológico foi o espelho de alteridade, tanto quanto o foi o selvagem cita.

Em que medida foi Heródoto o "pai da história”? Para Kury (1988), esse título deveria ser reservado para Tucídides, pois Heródoto manteve os próprios hábitos que condenava em seus antecessores, como o gosto pelo maravilhoso e o descaso pela cronologia, sempre que tal descaso servisse para reforçar alguma concepção moral. É o caso de uma suposta conversa entre Croisos e Sólon, cronologicamente impossível.

Por outro lado, a já referida ênfase em objetos de conhecimentos imutáveis condenou seu esforço ao esquecimento, na medida mesma em que tal ênfase negava o particular e, com ele, o entendimento do Outro. $\mathrm{O}$ próprio Heródoto também pecava na mesma direção.

Ao longo da obra repete-se um mesmo motivo: um tirano que aumenta o poder até o momento em que, ultrapassando os limites admissíveis, fracassa e perde, por vezes, tudo o que conseguiu... As Histórias desembocariam então no genérico e no previsível. (Darbo-Peschansky, 1998: 156)

No entanto, seus raciocínios se limitam ao singular, mesmo quando recorre a proposições genéricas, o que, para Aristóteles, eliminaria a possibilidade de constituir uma ciência da ação, dada a ausência de meios 
lógicos para demonstrar a universalidade das situações ou o significado dos acontecimentos.

Paradoxalmente, a própria concepção de história de Heródoto pode ter contribuído para limitar a apreciação da alteridade "selvagem". Também para ele, a história se explica pela ação da justiça, pela ação da diké: restabelecer uma ordem anterior. O sentido da história é restabelecer o equilíbrio. O selvagem é desprovido de diké e se a história é um encadeamento de fatos que tem como centro tal diké, estariam os selvagens fora da história?

Heródoto afirma que "os andrôfagos têm os mais selvagens dos costumes, não observam a justiça e não possuem lei alguma" (1988: IV - 106). A propósito dessa passagem diz Darbo-Peschansky:

É Homero quem nos fornece a pista, pois os andrófagos demonstram ter muito em comum com os cíclopes da Odisséia. Acaso Polífemes não se farta de carne humana? Não pertence ele a uma raça em que cada indivíduo faz sua própria lei? Os cíclopes no seu conjunto não têm nem sistema judiciário nem organização política. Verifica-se igual ausência de leis (nomoi) entre os andrófagos. (1998: 50)

É claro que Heródoto nunca afirma taxativamente que os andrôfagos são reais, mas são freqüentemente referidos como elementos de narrativa, nas quais parecem estar num estado de natureza. Estariam os citas nômades próximos a tal estado? Vale lembrar que a Cítia é o lugar onde Prometeu foi acorrentado, é vizinho do fim do mundo, é terra de passagem, é deserto.

Heródoto não foi bem recebido na Antigüidade grega. Com Tucídides ele se torna "pai da mentira", recaindo sobre ele a mesma estratégia que utilizou para desqualificar outros narradores. Com Ctésias, médico da corte de Artaxerxes, ele se torna logopoiós ("fazedor de logos"), epíteto que ele mesmo aplicara a outros. A autópsia (o realmente visto) cai em descrédito. Ao longo do tempo, Heródoto ia sendo atacado até o ataque máximo de Plutarco com Sobre a malignidade de Heródoto, no qual ele 
KlaAs Woortmann. O selvagem e a História. Heródoto e a questão do outro

á apresentado como difamador dos gregos e detrator do mais sagrado da religião grega. Para Plutarco é inaceitável o ponto de vista de que a religião egípcia tenha influenciado a religião grega (o que também coloca em dúvida o otimismo de Hogden, referido páginas atrás) tanto quanto seu "desrespeito" para com a Pítia. O interesse pelos costumes bárbaros fez com que fosse percebido como um philobarbaros, traidor da Grécia, mais que simplesmente mentiroso. É interessante observar que Plutarco percebia Alexandre como o helenizador dos povos "brutos" da Ásia e criador de cidades entre as tribos "selvagens". Não menos interessante é o fato de que Sócrates foi julgado por tentar introduzir divindades estrangeiras.

Para Aristóteles, Heródoto era um “fabulador". Estrabão o denuncia como praticante de philomúthia, como contador de mitos. Pode-se permitir a Hesíodo ou a Ésquilo, inventores conscientes do impossível, falar de seres fantásticos, como pigmeus, cinocéfalos ou cíclopes, poetas que foram, mas não se podia permitir que Heródoto o fizesse, mesmo manifestando ceticismo. Mesmo suas observações sobre "costumes estranhos", como diriam os etnólogos do século XIX, foram tidos como embuste por seus contemporâneos. E foi como mentiroso-mendaciorum patrem - que Heródoto foi por muitos percebido durante o medievo, período paradoxalmente alimentado pelas teratologias de Plínio, o Velho, Pomponius Mella e outros.

Seja como for, ainda que ambíguo aos olhos modernos, Heródoto era dotado de um espírito inquisitivo, curioso e, de maneira geral, no contexto de sua época, bastante objetivo. Tal como Megasthènes no século III A.C., não deixou de influenciar a filosofia grega no debate sobre padrões éticos absolutos: as descrições dos costumes de outros povos, ainda que helenizados, sugeriam, como vimos, que aquilo que era honroso num lugar poderia ser vergonhoso em outro, debate que ainda ocupa algum lugar na filosofia de nossos tempos e que incide sobre uma das pedras de toque da antropologia. Vale notar também que Heródoto optou por um modelo de explicação do particular essencialmente antropocêntrico. Sua narrativa mantém os deuses à distância, limitando sua argumentação causal 
ao tempo dos humanos, embora não negue o tempo dos deuses. "Heródoto demonstra um evidente cuidado em excluir da investigação certos temas que o obrigariam a introduzir os deuses em cena" (DarboPeschansky, 1998: 29).

Redescoberto no século XV pela tradução de Lorenzo Valla, foi no século seguinte que ele ganhou credibilidade, principalmente com a Apologia pro Herodoto, de Estienne: a inverossimilhança não permite concluir pela inveracidade. Estienne, baseado nas informações sobre diferenças culturais observadas após os Descobrimentos, defendia a plausibilidade das descrições de Heródoto sobre o mundo antigo. Se Heródoto descreveu costumes bastante estranhos, basta olhar para outros povos, de nós vizinhos, igualmente estranhos. Mais do que povos vizinhos, existiam agora, abertos ao olhar europeu, a uma nova autópsia, os recém-descobertos "selvagens" ameríndios. Uma nova alteridade tornava aceitável o discurso sobre a alteridade antiga. É nos ameríndios que se baseia também Léry para afirmar sua crença nos autores antigos: após ter residido entre os tupinambá, ele muda sua opinião sobre os antigos narradores de maravilhas. Infelizmente, porém, Léry faz dá crédito à teratologia de Plínio.

A partir do século XVIII o selvagem começa a ser transformado no primitivo. A observação de Duchet merece ser transcrita:

A metamorfose do homem selvagem em homem primitivo, porque faz dele um ser histórico, torna ao mesmo tempo possível um olhar antropológico; nele, enfim, o homem europeu pode se reconhecer e aprender a se conhecer: basta-lhe abrir o espaço de sua própria história e de fazer figurar o homo sylvestris entre seus ancestrais. Assim se constitui definitivamente a dupla selvagem-civilizado que... comanda todo o funcionamento do pensamento antropológico até o início do século XIX. O homem selvagem confunde-se com seus duplos, citas ou germânicos, e toma lugar a seu lado num vasto mito das origens. (1995: 15; grifos meus)

Se Heródoto atravessou a Idade Média como mentiroso, não deixa de ser irônico que fragmentos da História tivessem circulado em cópias 
KlaAs Woortmann. O selvagem e a História. Heródoto e a questão do outro

deformadas no período medieval; o que se copiou foram principalmente suas indulgências exotizantes, talvez porque fossem tão necessárias para a construção da identidade cristã quanto o foram para a identidade grega. É significativo que outros autores, mais adeptos da teratologia, tivessem feito maior sucesso e que suas construções tivessem desembarcado no continente americano.

Em conclusão, a figura do selvagem existe no pensamento ocidental desde a Antigüidade. Para os gregos, era um recurso para afirmar sua distinção como hemeros. Aplicada a povos como os citas "nômades", excluía tais povos da humanidade plena e tornava a alteridade impensável. Heródoto afastou-se do senso comum, como foi visto; mesmo ele, contudo, não conseguiu construí-los como um povo em si mesmo, mas apenas como recurso narrativo voltado para a construção de uma identidade grega.

\section{Notas}

1 Agradeço a colaboração de meus colegas Alcida R. Ramos, Ellen F. Woortmann, Luís Roberto C. de Oliveira e Mariza Peirano que, de variadas maneiras, contribuíram para que este trabalho pudesse ser realizado.

2 O pensamento grego não possuía o conceito de civilização, em parte coberto pela noção de pólis. Portanto, utilizo aqui o termo civilização de forma um tanto arbitrária, em seu sentido contemporâneo e de forma a englobar o conteúdo polissêmico de pólis e a oposição grego-bárbaro/selvagem.

\section{Bibliografia}

ARIÈS, P.

1989 O Tempo da História, Rio de Janeiro, Francisco Alves. 


\section{ARISTÓTELES}

1985 Política, Brasília, Editora Universidade de Brasília. Tradução de Mário da Gama Kury.

BARTRA, R.

$1994 \quad$ Wild Men in the Looking Glass. The mythic origins of European Otherness, Ann Arbor, The University of Michigan Press.

COLLINGWOOD, R.G.

1994 A idéia de História, Lisboa, Editorial Presença.

\section{COULANGES, F.}

1981

A cidade antiga, São Paulo, Martins Fontes.

DARBO-PESCHANSKY,C.

1998 O discurso do particular. Ensaio sobre a investigação de Heródoto, Brasília, Editora Universidade de Brasília.

\section{DOUGLAS, $\mathrm{M}$.}

1966 Purity and Danger, London, Routledge \& Kegan Paul.

DUCHET, M.

1995

Anthropologie et Histoire au Siècle des Lumières, Paris, Albin Michel.

\section{GLACKEN, C. J.}

1967 Traces on the Rhodian Shore, Berkeley/Los Angeles/London, University of California Press. 
KlaAs Woortmann. O selvagem e a História. Heródoto e a questão do outro

\section{HARTOG, F.}

1980 Le Miroir d'Hérodote. Essai sur la représentation de l'autre, Paris, Éditions Gallimard.

HERÓDOTOS

1988

História, Brasília, Editora Universidade de Brasília. Tradução de Mário da Gama Kury.

HOGDEN, M. T.

1964 Early Anthropology in the Sixteenth and Seventeenth Centuries, Philadelphia, University of Pennsylvania Press.

KURY, M.da G.

1988 Introdução a Heródoto - História, Brasília, Editora Universidade de Brasília.

LE GOFF, J. \& VIDAL-NAQUET, P.

1979 Lévi-Strauss en Brocéliande, in BELLOUR, R. \& CLÉMENT, C. (orgs.), Claude Lévi-Strauss, Paris, Gallimard.

MOMIGLIANO, A.

1975 “The fault of the Greeks”, Deadalus, vol. 104(2): 10-18.

ROWE, J.H.

1965 "The Renaissance Foundations of Anthropology", American Anthropologist, vol. 67: 1-20.

SAHLINS, $M$.

1978 Stone Age Economics, London, Tavistock Publications. 
Revista de Antropologia, São Paulo, USP, 2000, v. 43 nº 1

THOMAS, K.

1971

Religion and the Decline of Magic, Londres, Weidenfeld \& Nicolson.

WHITE, H.

1994

Trópicos do discurso; ensaios sobre a crítica da cultura, São Paulo, Edusp.

\begin{abstract}
The paper focuses on the limits imposed to the understanding of alterity in Greek thought by its theory of history and by the opposition between epistème and doxa. The failure to appreciate the particular, the event in its own meaning, also imposed limits to the development of an ethnographic perspective. In this context, the paper examines the meaning of the category "savage" (or wild man) in Greek thought with special reference to the role played by Scytes in Herodotus' History.
\end{abstract}

KEY-WORDS: savages, Greek thought, history, Scytes, Herodotus, particular, event, mythology, barbarians. 